\title{
Comparing Water Quantity between Korean and Japanese River
}

\section{Noh, Jaekyoung}

Department of Agricultural and Rural Engineering, College of | Science for Bioproduction Environment, Faculty of Agriculture, Kyushu University

\section{An, Hyunuk}

Department of Agricultural and Rural Engineering, College of | Science for Bioproduction Environment, Faculty of Agriculture, Kyushu University

Shinogi, Yoshiyuki

Science for Bioproduction Environment, Faculty of Agriculture, Kyushu University | Laboratory of Irrigation and Water Management, Department of Bioproduction Environmental Sciences, Faculty of Agriculture, Kyushu University

Oh, Taek-Keun

Department of Bio-Environmental Chemistry, College of Agriculture and Life science, Chungnam National University | Science for Bioproduction Environment, Faculty of Agriculture, Kyushu University

他

https://doi.org/10.5109/1854024

出版情報：九州大学大学院農学研究院紀要. 62 (2)，pp.483-492，2017-09-08. Faculty of Agriculture, Kyushu University

バージョン :

権利関係 : 


\title{
Comparing Water Quantity between Korean and Japanese River
}

\author{
Jaekyoung NOH ${ }^{1}$, Hyunuk AN ${ }^{1}$, Yoshiyuki SHINOGI ${ }^{2}$, Taek-Keun OH$^{3}$ and Jaenam LEE ${ }^{4 *}$
}

\author{
Science for Bioproduction Environment, Faculty of Agriculture, Kyushu University, \\ Hakozaki 6-10-1, Higashi-ku, Fukuoka city 812-8581, Japan \\ (Received April 28, 2017 and accepted May 10, 2017)
}

\begin{abstract}
To compare water quantity and quality on the Korean and Japanese rivers, two watersheds with similar watershed area were selected. The one from Korea is called the Yongdam dam watershed in the Geum river basin with watershed area of $930 \mathrm{~km}^{2}$, the other from Japan is called the Nakama watershed in the Onga river basin with watershed area of $925 \mathrm{~km}^{2}$. The 3 discharge, 2 water quality stations from Korea and 14 discharge, 2 water quality stations from Japan were selected and analyzed to determine flow durations. Korean data were collected during 2000 to 2013 from water management information system. Japanese rainfall and discharge data were collected during 1980 to 2013 from water information system. Numbers of station-year were 38 on Korea and 436 on Japan. Annual rainfalls were averaged to $1418.1 \mathrm{~mm}$ ranged from $778.2 \mathrm{~mm}$ to $2061.9 \mathrm{~mm}$ on Korea and $1972.5 \mathrm{~mm}$ ranged from $845.0 \mathrm{~mm}$ to $3623.0 \mathrm{~mm}$ on Japan, from which Japanese showed more 1.39 times than Korean. Streamflow data were generated daily by the ONE (One parametric New Exponential) hydrological model. Simulated annual streamflows were averaged to $854.2 \mathrm{~mm}$ ranged from $273.6 \mathrm{~mm}$ to $1571.4 \mathrm{~mm}$ on Korea and $1481.6 \mathrm{~mm}$ ranged from $360.6 \mathrm{~mm}$ to $3177.4 \mathrm{~mm}$ on Japan, from which Japanese showed 1.73 times more than Korean. The flow durations with 10 year frequency were compared, in which the $1^{\text {st }}$ flows were $18.77 \mathrm{~mm}$ in Korea and $88.27 \mathrm{~mm}$ in Japan, the $95^{\text {th }}$ flows of 0.43 and 3.97 , the $185^{\text {th }}$ of 0.13 and 1.92 , the $275^{\text {th }}$ of 0.06 and 0.93 , and the $355^{\text {th }}$ of 0.05 and 0.30 , respectively. Japanese flows were 4 to 15 times more than Korean. On the other hand, mean flow durations showed the $1^{\text {st }}$ flows of $67.11 \mathrm{~mm}$ and 88.27 , the $95^{\text {th }}$ of 1.58 and 3.97 , the $185^{\text {th }}$ of 0.51 and 1.92 , the $275^{\text {th }}$ of 0.21 and 0.93 , and the $355^{\text {th }}$ of 0.08 and 0.30 , respectively. Japanese flows also showed 1.3 to 4.4 times more than Korean. Mean annual runoff ratios were $58.2 \%$ ranged from $35.2 \%$ to $76.2 \%$ on Korean river, and $73.7 \%$ from $42.6 \%$ to $90.0 \%$ on Japanese river. Japanese runoff ratio also showed 1.27 times more than Korean. This result shows some more necessities and difficulties on low flow management in Korean river than in Japanese river.
\end{abstract}

Key words: Korean and Japanese river, Streamflows, Hydrological model, Flow duration

\section{INTRODUCTION}

The instream flow is the flow that should be remained in the river for protecting aquatic ecosystem and various natural resources. The first appearance of its concept was 1960s in the law of the Korea. 'Instream Flow Guideline' was built in mid 1990s by government and the term 'instream flow' appeared in the Korean River Act. In late 1990s, instream flows for major rivers were calculated and officially notified in 2006 for management and monitoring. 'Instream Flow Guideline' revised in 2009 and nationwide evaluation project of instream flow had conducted from 2007 to 2011 according to this new guideline. After this project, the instream flows of tributaries were made to public announcement in 2015 (Kang et al., 2016).

\footnotetext{
1 Department of Agricultural and Rural Engineering, College of Agriculture and Life science, Chungnam National University, Daejeon 305-764, Korea

2 Science for Bioproduction Environment, Faculty of Agriculture, Kyushu University, Hakozaki 6-10-1, Higashi-ku, Fukuoka city 812-8581, Japan

Department of Bio-Environmental Chemistry, College of Agriculture and Life science, Chungnam National University, Daejeon 305-764, Korea

${ }^{4}$ Rural Research Institute, KRC, Ansan, Gyeonggi-do,15634, Korea

* Corresponding author (E-mail: melody_jn@naver.com) (J. LEE)
}

Heightening irrigation reservoirs, as a part of the 4major river restoration project, have implemented to secure not only additional agricultural water but also instream flow for water quality improvement. Using SWAT model, instream flow effects on water quality of downstream were evaluated to show $2 \sim 10 \%$ water quality improvement effect on nutrients, as well as 1 8\% water quantity increasing effect (Jee et al., 2012).

Water quantity and quality are very closely related. Several studies have been performed to manage water quantity and quality effectively in around world river. To provide guidance on the sustainable use of a river's waterresources, the Building Block Methodology (BBM) has been developed for assessing the instream flow requirement for any river in South Africa (King and Louw, 1998). In order to protect the biointegrity and function of the river ecosystem in Xiangxi river, the theory system of instream environmental flow was categorizedinto three hierarchies, namely minimum required instream flow (hydrological level), minimum instream environmental flow (biospecies level), and optimum instream environmental flow (ecosystem level) (Li et al., 2009). Environmental flow values were predicted from variables such as the flow equalled or exceeded 347 days per year (Q347), or the average for the period of record of minimum mean monthly flows from the analysis of four homogeneous regions in the Ebro watershed (Alcázar and Palau, 2010). The Taiwan ecohydrol- 
ogy indicator system (TEIS) was developed to identify hydrologic statistics most appropriate to Taiwan fisheries using 52 long-term flow records from 23 undisturbed watersheds in Taiwan (Chang et al., 2008, 2011). A global imperative to set $e$-flows, including an emerging trend to set standards at the regional scale, has led to developments of hydrological and hydraulic approaches but expert judgment remains a critical element of the complex decision-making process around water allocations (Petts, 2009). Revisions of laws and regulations, and redefinition of societal goals and policies, are essential to enable managers to use the best science to develop appropriate management programs (Poff et al., 1997). The 'Range of Variability Approach' (RVA) was derived from aquatic ecology theory concerning the critical role of hydrological variability, and associated characteristics of timing, frequency, duration, and rates of change, in sustaining aquatic ecosystems (Richter et al., 1997). A method of mapping flow regime classes using boosted regression trees (BRT) was developed, in which automatically fits non-linear functions and interactions between explanatory variables of flow regimes, both of which can be expected when comparing responses between complex systems such as watersheds (Snelder et al., 2009). Multivariate time series analysis for monthly natural flow was studied, in whichthirty years of pre-regulation time series of monthly discharge, rainfall, and maximum temperature in Murrumbidgee Catchment were used to build the regressive models which represent the natural state of catchment hydrology (Wen, 2009).

In this study, using daily simulated streamflow data, comparison of water quantity between Korean and Japanese rivers was performed to refer an efficient water management by selecting one watershed with similar size each country.

\section{MATERIALS AND METHODS}

\section{Study areas}

Watersheds with similar area were selected, in which Yongdam dam watershed with $930 \mathrm{~km}^{2}$ has 3 discharge stations in the Geum river basin in Korea as shown in Fig. 1 and Nakama watershed with $925 \mathrm{~km}^{2}$ has 14 discharge stations in the Onga river basin in Japan as shown in Fig. 2.

Yongdam dam watershed has the elevation range from 870 meters at the top of mount Sinmu to 263.5 meters in the full water level of Yongdam dam, which is located in $329.7 \mathrm{~km}$ from the estuary and $53.7 \mathrm{~km}$ from the top of mount Sinmu (http://www. wamis.go.kr). Nakama station watershed has the elevation range from 1180 meters at the top of mount Hiko to 6.905 meters in the planned high water level at the Nakama station, which is located in $10.8 \mathrm{~km}$ from the estuary and $39.5 \mathrm{~km}$ from the top of mount Hiko (http:// www1.river.go.jp).

Land uses of Yongdam dam watershed consist of forest $79.72 \%$, paddy field $8.95 \%$, field $5.38 \%$, and deforest $5.95 \%$. Land uses of Onga river basin with watershed

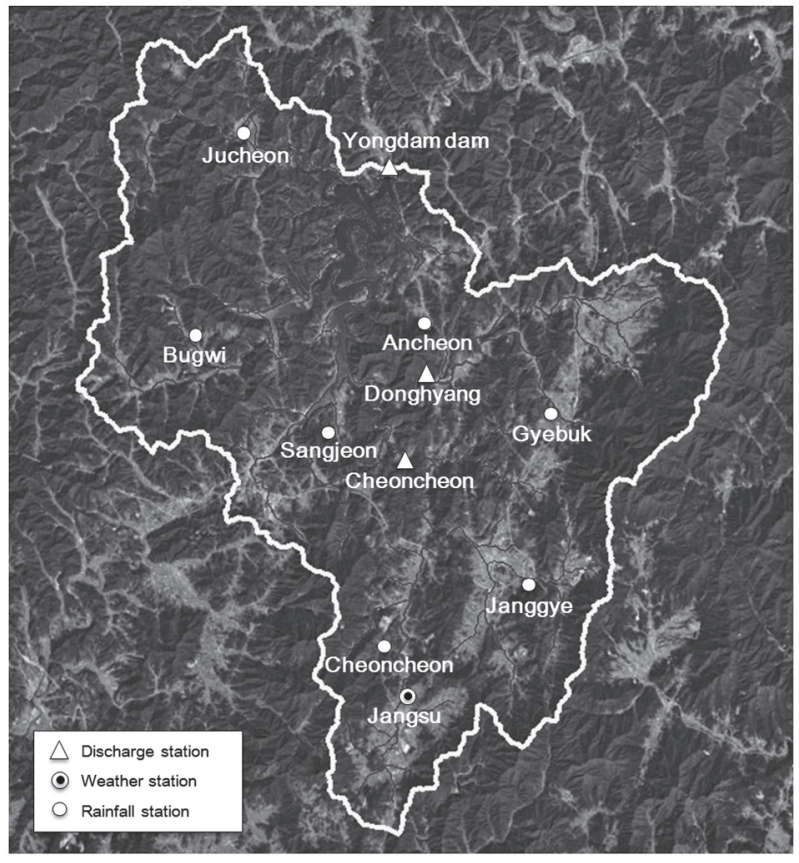

Fig. 1. Locations of discharge, rainfall, and weather stations within Yongdam dam watershed.

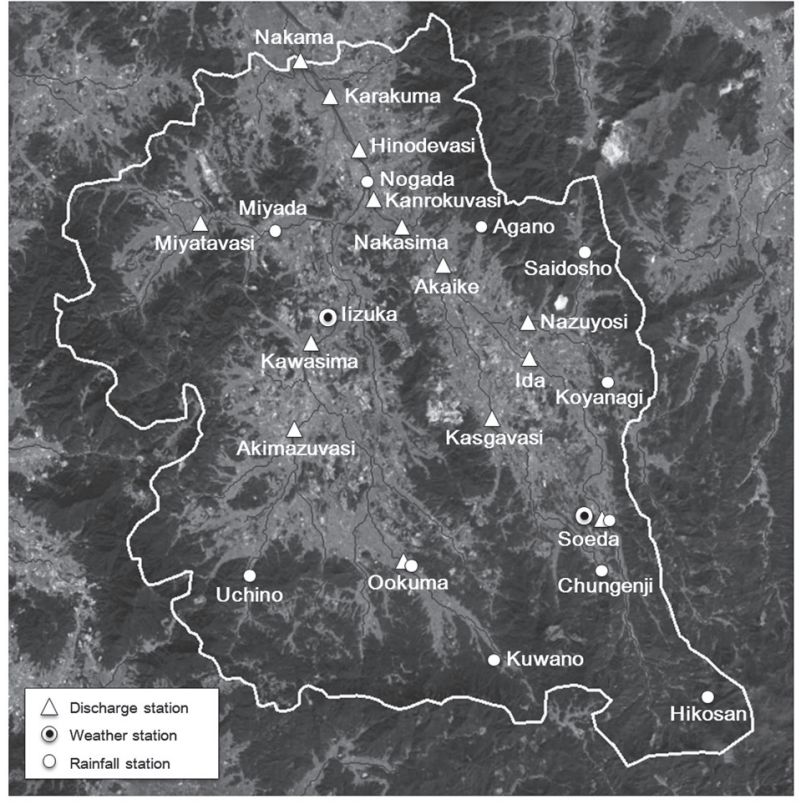

Fig. 2. Locations of discharge, rainfall, and weather stations within Nakama station watershed.

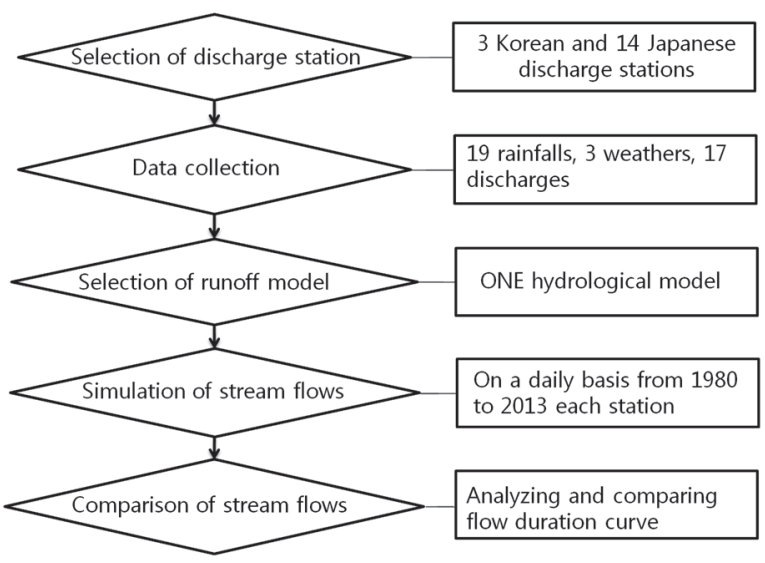

Fig. 3. Study flow and content. 
area of $1036 \mathrm{~km}^{2}$ consists of forest $66.89 \%$, paddy field $23.05 \%$, field $2.85 \%$, golf $1.41 \%$, and deforest $5.80 \%$ (Tran et al., 2011).

Study flow and content include selection of discharge station, data collection, selection of runoff model, simulation of streamflows, and comparison of stream flows as shown in Fig. 3.

\section{Data sources}

Data needed for simulating streamflows area rainfall, evaporation, and discharge data. Evaporation data which are necessary to simulate runoff, have not been observed in most of meteorological stations in Japan. To generate evaporation data using multiple regression, weather data such as temperature, rainfall, wind speed, humidity, and sunshine duration data were collected on a daily basis from Japan Meteorological Agency (http:// www.jma.go.jp). Measured streamflow data were collected to verify the result simulated by runoff model in the water information system (http://www1.river.go.jp). Korean data were collected from Korea Meteorological Administration (http://www.kma.go.kr), and water management information system called WAMIS (http://www. wamis.go.kr).

Selected stations were shown in Table 1, in which Yongdam dam watershed in Korea included 7 rainfall, 1 weather, and 3 discharge stations, and Nakama station watershed in Japan included 11 rainfall, 2 weather, and 14 dischargestations.

\section{Evaporation generation}

Izuka meteorological station observes temperature, rainfall, wind speed, humidity, sunshine duration on a daily basis, but Soeda station do not observe humidity. Evaporation is not observed in Japanese stations. But some 20 meteorological stations in Korea have observed evaporation on a daily basis. Daejeon station was selected to derive daily evaporation estimation equation. Using multiple regression method, two equations were derived as equation (1), (2), respectively, in where EP means evaporation, AT average temperature, OP rainfall, WS wind speed, RH relative humidity, and DS sunshine duration. Fig. 4 shows scatter diagram and equal value line between observed and estimated daily evaporation. In high values, estimated values were shown lower than observed values. Fig. 5 shows daily and monthly comparisons between observed and estimated evaporation, in which also the estimated was lower than the observed. Estimated evaporation showed a very high reasonable fitting on reservoir inflows in the study by Noh and Lee (2001).

$$
\begin{aligned}
\mathrm{EP}= & 1.925+0.126 \times \mathrm{AT}-0.009 \times \mathrm{OP}+0.201 \times \mathrm{WS} \\
& -0.032 \times \mathrm{RH}+0.229 \times \mathrm{DS},\left(\mathrm{R}^{2}=0.817\right) \cdots \cdots \cdots(1) \\
\mathrm{EP}= & -0.685+0.111 \times \mathrm{AT}-0.013 \times \mathrm{OP}+0.299 \times \mathrm{WS} \\
& +0.293 \times \mathrm{DS},\left(\mathrm{R}^{2}=0.795\right) \cdots \cdots \cdots \cdots \cdots \cdots \cdots \cdots \cdots \cdots \cdots \cdots \cdots \cdots \cdots \cdots
\end{aligned}
$$

\begin{tabular}{|c|c|c|c|c|c|}
\hline \multicolumn{3}{|c|}{ Yongdam dam watershed } & \multicolumn{3}{|c|}{ Onga river basin } \\
\hline Rainfall (7) & Weather (1) & Discharge (3) & Rainfall (11) & Weather (2) & Discharge (14) \\
\hline Jucheon & Jangsu & Cheoncheon $(290.9)^{\mathrm{a}}$ & Hikosan & Iizuka & Soeda (76) \\
\hline Bugwi & & Donghyang (164.4) & Chungenji & Soeda & Ida (127) \\
\hline Ancheon & & Yongdam dam (930.0) & Koyanagi & & Nazuyosi (47) \\
\hline Sangjeon & & & Saidosho & & Kasgavasi (72) \\
\hline Cheoncheon & & & Kuwano & & Akaike (309) \\
\hline Janggye & & & Ookuma & & Nakasima (326) \\
\hline \multirow[t]{8}{*}{ Gyebuk } & & & Uchino & & Ookuma (42) \\
\hline & & & Kawasima & & Akimazuvasi (113) \\
\hline & & & Agano & & Kawasima (292) \\
\hline & & & Nogada & & Kanrokuvasi (366) \\
\hline & & & Miyada & & Hinodevasi (695) \\
\hline & & & & & Miyatavasi (123) \\
\hline & & & & & Karakuma (887) \\
\hline & & & & & Nakama (925) \\
\hline
\end{tabular}

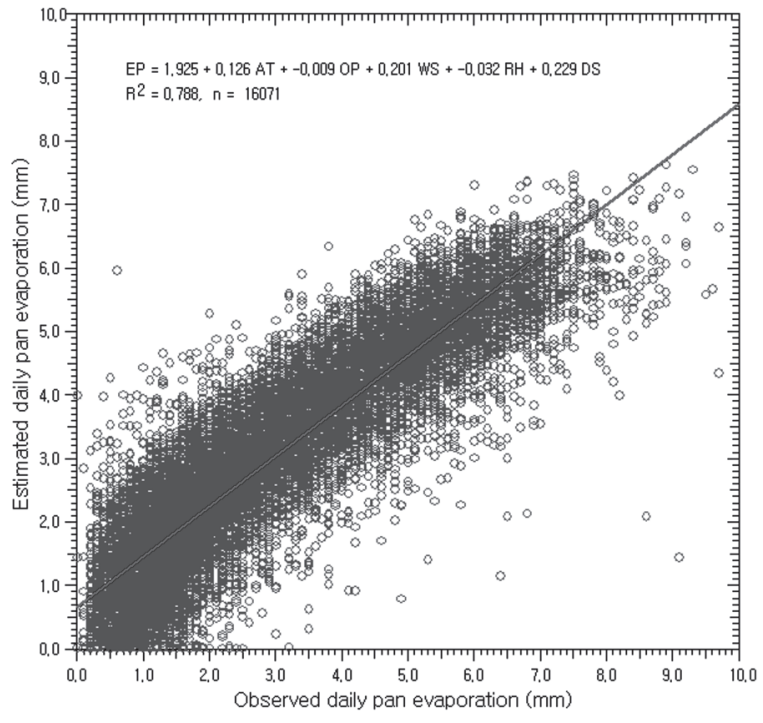

Fig. 4. Equal value line of generated daily evaporation.

Table 1. Selected stations on rainfall, weather, discharge, water quality in Korean and Japanese rivers

\footnotetext{
a) Numeric values in parentheses are the watershed area $\left(\mathrm{km}^{2}\right)$.
} 


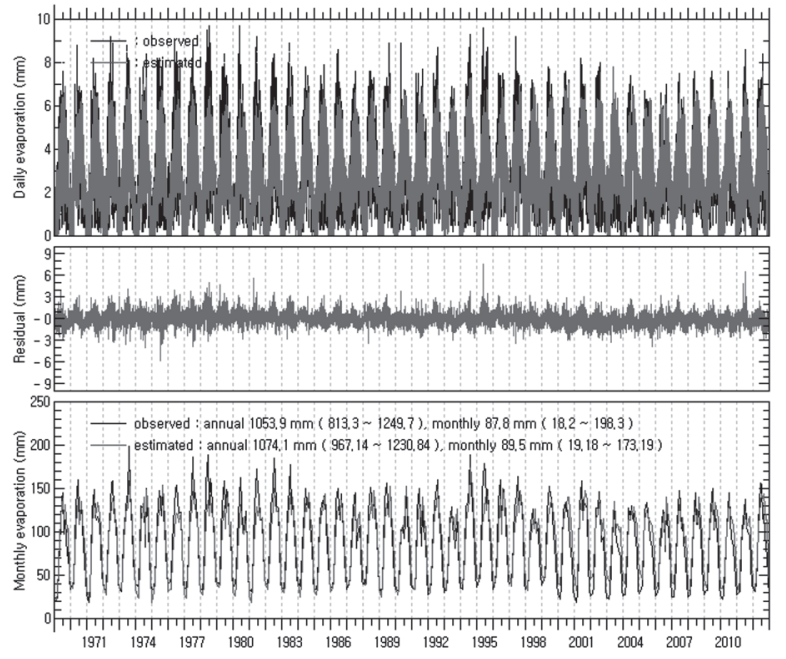

Fig. 5. Comparisons of daily and monthly evaporations.

\section{Selection of runoff model}

Runoff models are divided into lumped and distributed model. Distributed model is not appropriate to simulate and to evaluate long term streamflow data on several sites. In Korea, conceptual lumped runoff model called DAWAST (DAilyWAtershedSTreamflow model) was developed firstly by Noh (1991). Second one was TPHM (Two Parametric Hyperbolic Model) by Kim (2001). Third one was ONE (One parametric New Exponential hydrological model) by Noh, by which applied to plan reservoir building for supplying water to upland areas in Dodota area, Ethiopia (2012). Noh and Lee (2011) compared DAWAST and TPHM models to apply reservoir inflow in Korea, which drove Noh to develop new model called ONE (2012).

A schematic diagram of ONE model is shown in Fig. 6 , in which parameter is just one expressed as alpha $(\alpha)$. Equation (3) is the kernel function of ONE model, in where $\mathrm{Q}$ means daily runoff, $\mathrm{S}$ means daily watershed soil storage water, $\alpha$ is only one parameter, and (i) denote time (day). Using daily inflow data from 16 multipurpose dam in Korea, ONE model was generalized as

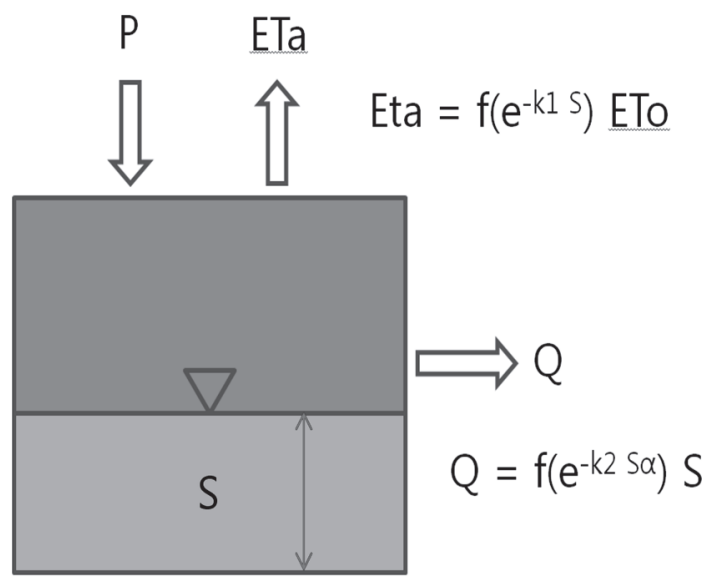

Fig. 6. A schematic diagram of ONE model.

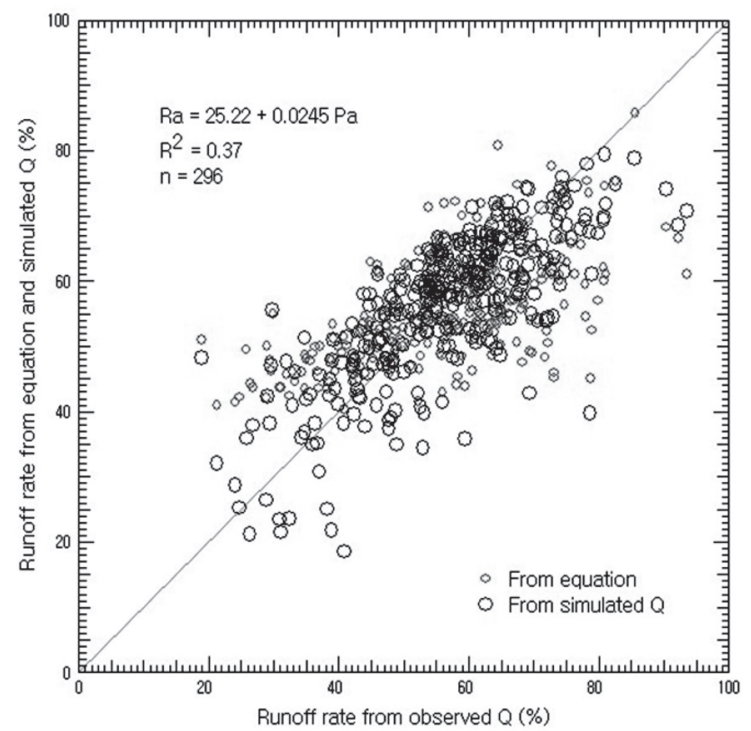

Fig. 7. Generalization of ONE model.

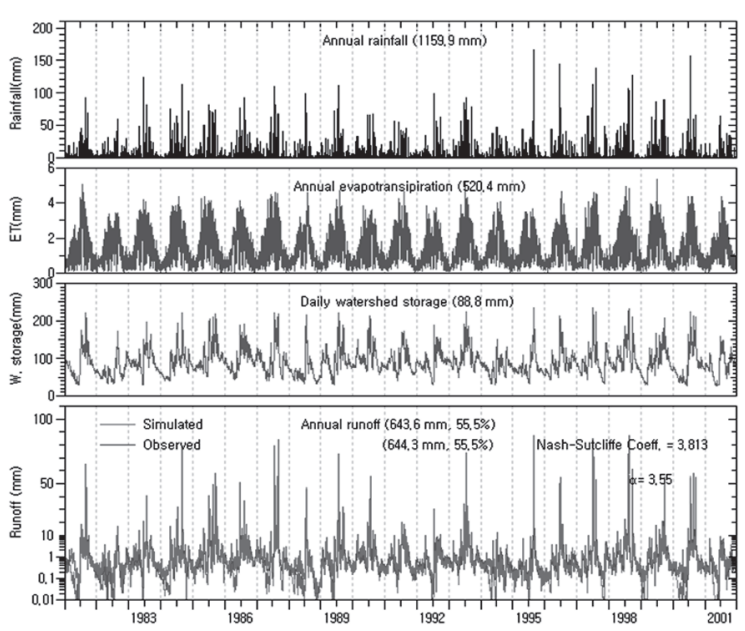

Fig. 8. Daily simulated streamflows by ONE model.

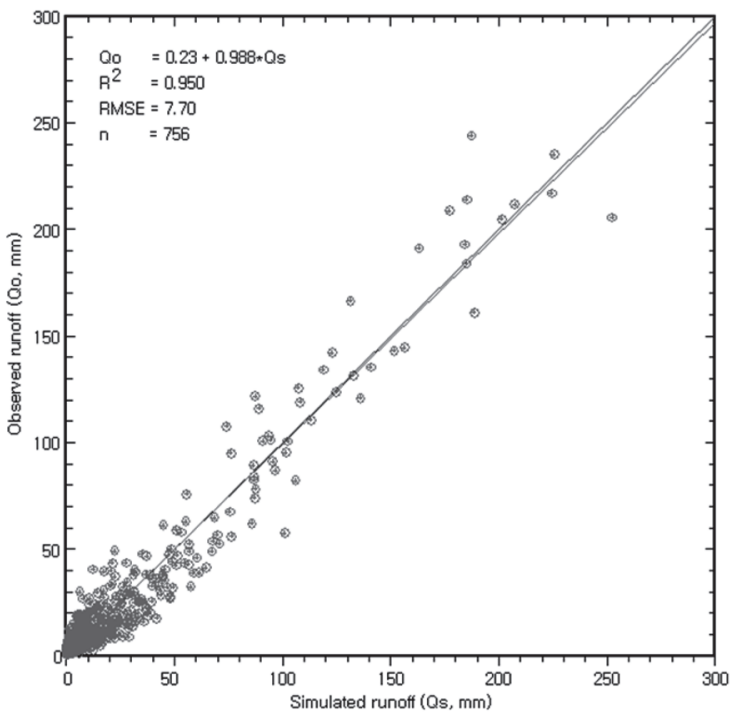

Fig. 9. A verification example of ONE model. 
Fig. 7 and equation (4) in where Qr means annual runoff ratio, $\mathrm{Pa}$ means annual rainfall. Using equation (4), one parameter $\alpha$ is determined very easily. Daily simulated streamflows by generalized parameter $\alpha$ were well fitted to observed data to an astonishing degree as shown in Fig. 8 and 9. From the above result, the ONE model was selected to simulate and to evaluate streamflows in Korean and Japanese rivers of this study.

$$
\begin{aligned}
& \mathrm{Q}_{(\mathrm{i})}=\mathrm{S}_{(\mathrm{i})} \times\left(1-\mathrm{e}^{-0.003 \times \mathrm{S}(\mathrm{i})}\right)^{\left[\left(0.2+\mathrm{e}^{-0.001 \times S(\mathrm{i})} \times \alpha\right]\right.} \\
& \mathrm{Qr}=25.22+0.0245 \times \mathrm{Pa} \ldots \ldots \ldots \ldots \ldots \ldots \ldots \ldots \ldots
\end{aligned}
$$

\section{Flow duration analysis}

A flow duration curve (FDC) is one of the most informative methods of displaying the complete range of river discharges from low flows to floodevents. It is a relationship between any given discharge value and the percentage of time that this discharge is equaled or exceeded, or in other words - the relationship between magnitude and frequency of streamflow discharges (Smakhtin, 2001).

Annual averaged daily streamflows were sorted from high to low, and the $1^{\text {st }}, 95^{\text {th }}, 185^{\text {th }}, 275^{\text {th }}$, and $355^{\text {th }}$ flows were compared. To secure and maintain a relative reference, daily streamflows with 10 year frequency were selected and compared in this study.

\section{RESULTS}

\section{Simulation of daily streamflows}

Areal daily rainfalls were prepared by areal weight using point rainfall data nearby watersheds as shown in Fig. 10. And evaporation data were generated by equation (1), (2), in where areal rainfall data were used. Fig. 11 shows an example of daily generated evaporation.

Fig. 12 and Fig. 13 show examples of daily hydrographs in Yongdam dam watershed and Nazuyoshi station watershed, respectively. Simulated data were well fitted to observed data. Fig. 14 and Fig. 15 show examples of equal value lines on decadal streamflows ana-

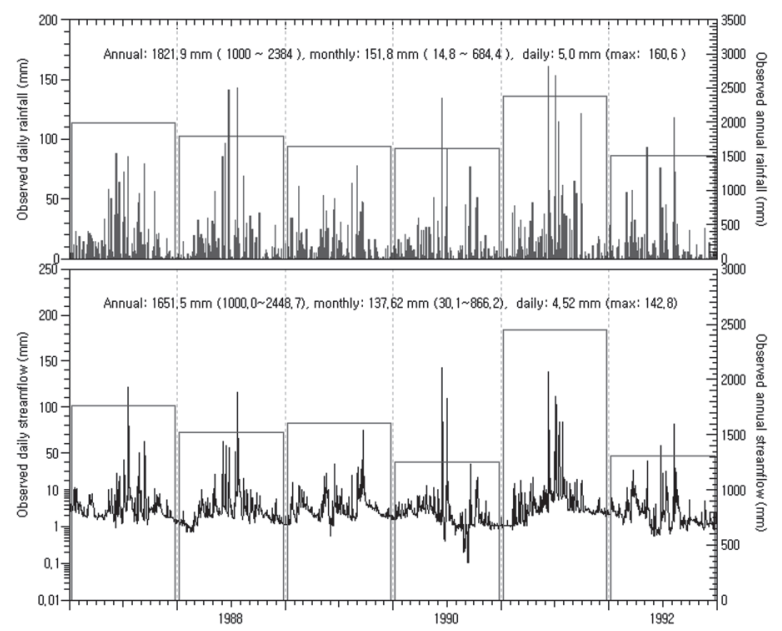

Fig. 10. An example of areal rainfall and observed streamflow.

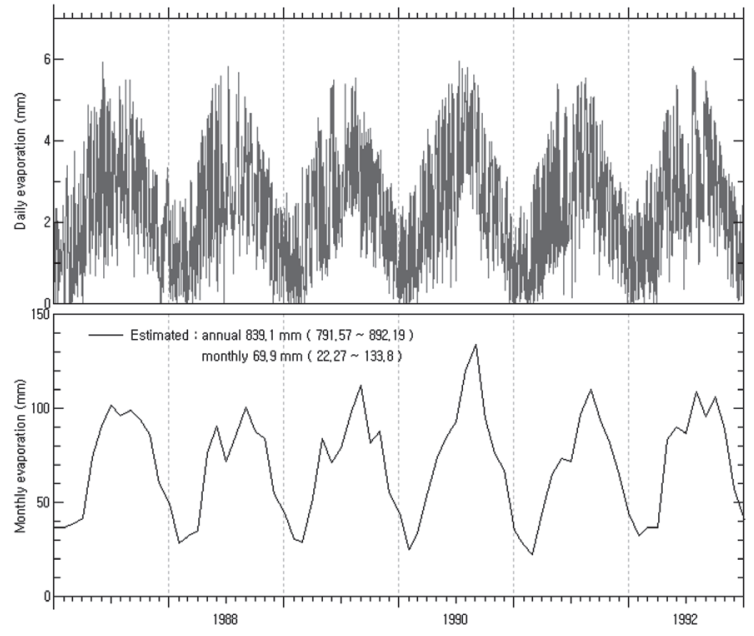

Fig. 11. An example of daily generated evaporation.

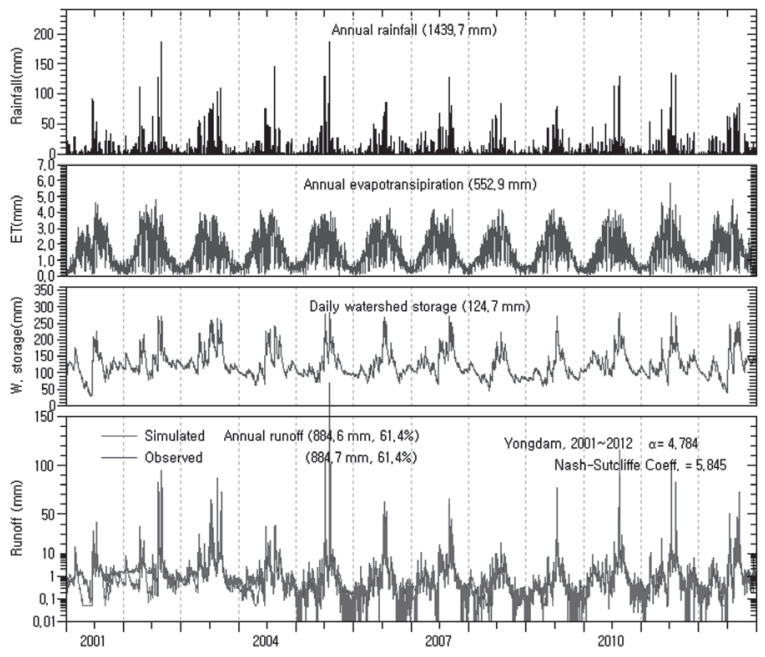

Fig. 12. An example of daily simulated streamflow in Yongdam dam, Korea.

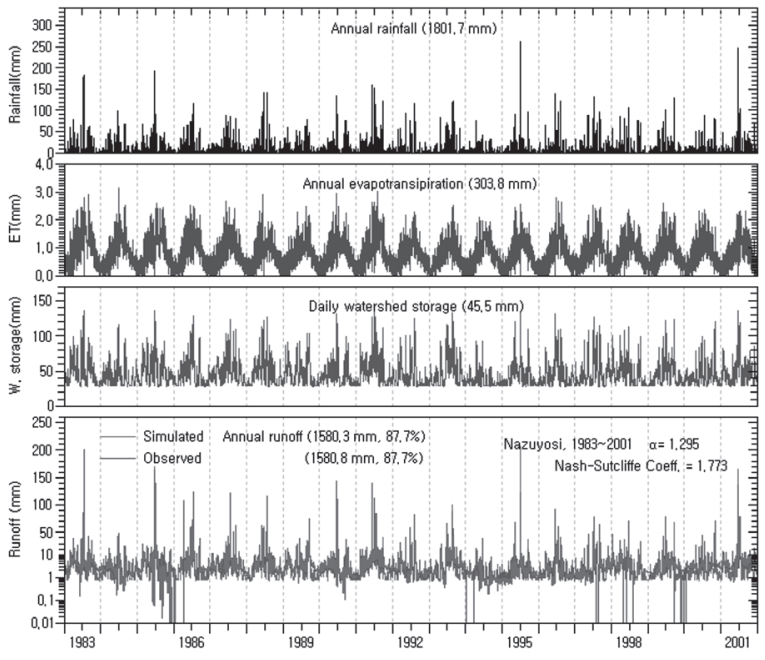

Fig. 13. An example of daily simulated streamflow in Nazuyosi station, Japan. 


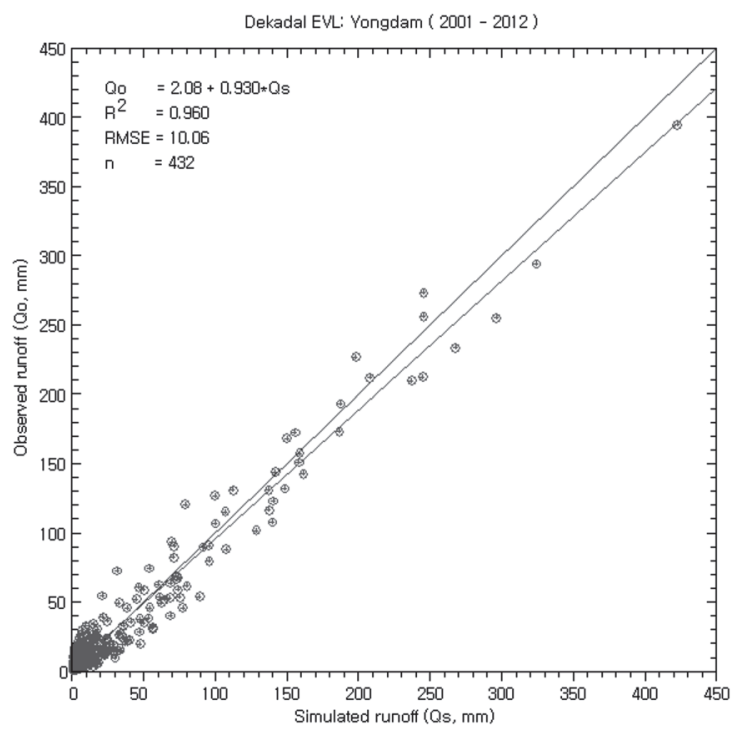

Fig. 14. An example of comparing equal lines on dekadal streamflows in Yongdam dam, Korea.

lyzed from daily simulated streamflow data, respectively, in which equal value lines were focused in 45 degrees and data were scattered nearby lines.

With the above same method, streamflows of other 16 stations were checked, prepared and simulated on a daily basis. Table 2 shows comprehensive annual averaged result on daily simulated streamflows in Korean and Japanese rivers. Annual rainfalls were ranged from $1356.4 \mathrm{~mm}$ to $1473.4 \mathrm{~mm}$ on Korean river and were ranged from $1613.9 \mathrm{~mm}$ to $2470.7 \mathrm{~mm}$ on Japanese river. Simulated annual streamflows were ranged from $794.1 \mathrm{~mm}$ to $906.1 \mathrm{~mm}$ on Korean watershed and were

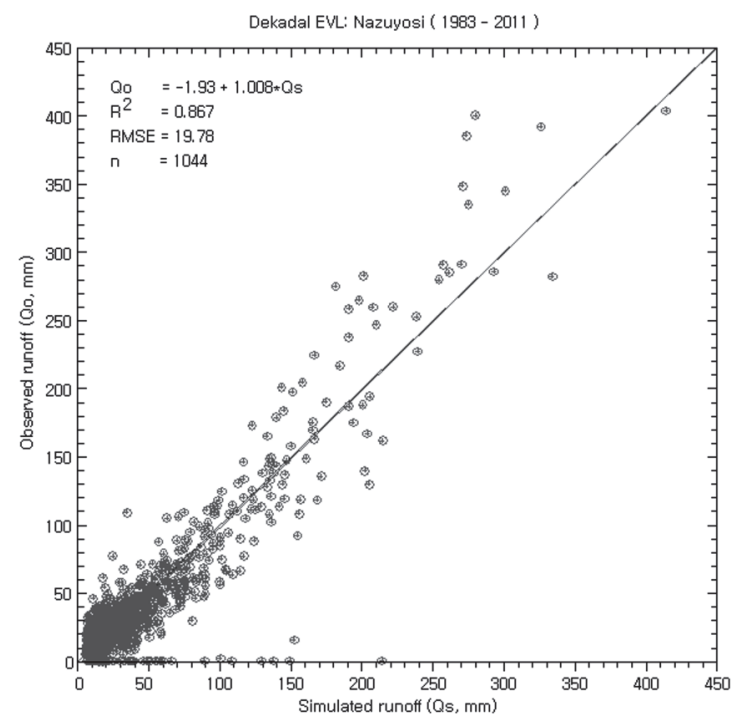

Fig. 15. An example of comparing equal lines on dekadal streamflows in Nazuyosi station, Japan.

ranged from $1045.8 \mathrm{~mm}$ to $2120.1 \mathrm{~mm}$ on Japanese watershed. Runoff ratios were ranged from $58.5 \%$ to $61.0 \%$, and were ranged from $64.8 \%$ to $86.0 \%$, respectively.

\section{Flow duration analysis}

Flow duration curves were derived from daily simulated streamflow data as shown in Yongdam dam and Nazuyosi station of Fig. 16 and Fig. 17, respectively. Here are used annual mean and 10 year frequency data series. Unit of streamflows were expressed in $\mathrm{mm} / \mathrm{d}$ and $\mathrm{m}^{3} / \mathrm{s}$. Unit of $\mathrm{mm}$ is very convenient to compare relative

Table 2. Comprehensive annual averaged result on daily simulated streamflows in Korean and Japanese rivers

\begin{tabular}{|c|c|c|c|c|c|c|c|c|}
\hline \multirow{2}{*}{ River } & \multirow{2}{*}{ Watershed } & \multirow{2}{*}{$\begin{array}{c}\text { Area } \\
\mathrm{km}^{2}\end{array}$} & \multirow{2}{*}{ Duration } & \multicolumn{2}{|c|}{ Annual rainfall } & \multicolumn{2}{|c|}{ Annual streamflow } & \multirow{2}{*}{$\frac{\text { Runoff ratio }}{\%}$} \\
\hline & & & & $\mathrm{mm}$ & $\mathrm{Mm}^{3}$ & $\mathrm{~mm}$ & $\mathrm{Mm}^{3}$ & \\
\hline \multirow{3}{*}{ Yongdam dam } & Cheoncheon & 290.9 & 2002-2014 & $1,473.4$ & 428.62 & 906.0 & 263.55 & 61.0 \\
\hline & Donghang & 164.4 & $2002-2014$ & $1,356.4$ & 222.99 & 794.1 & 130.55 & 58.5 \\
\hline & Yongdam & 930.0 & 2001-2014 & $1,439.7$ & $1,338.91$ & 871.6 & 810.61 & 60.5 \\
\hline \multirow{14}{*}{ Onga } & Soeda & 76.0 & $1983-2013$ & $2,470.7$ & 187.77 & $2,120.1$ & 161.13 & 85.8 \\
\hline & Ida & 127.0 & $1980-2013$ & $2,109.0$ & 267.84 & $1,621.4$ & 205.92 & 76.9 \\
\hline & Nazuyosi & 47.0 & $1983-2013$ & $1,828.9$ & 85.96 & $1,572.5$ & 73.91 & 86.0 \\
\hline & Kasgavasi & 72.0 & 1983-2013 & $1,814.6$ & 130.65 & $1,258.8$ & 90.64 & 69.4 \\
\hline & Akaike & 309.0 & $1982-2013$ & $2,014.2$ & 622.40 & $1,502.8$ & 464.36 & 74.6 \\
\hline & Nakasima & 326.0 & 1980-2013 & $1,975.8$ & 644.11 & $1,454.6$ & 474.21 & 73.6 \\
\hline & Ookuma & 42.0 & $1980-2013$ & $2,116.3$ & 88.88 & $1,631.0$ & 68.50 & 77.1 \\
\hline & Akimazuvasi & 113.0 & 1980-2013 & $2,154.9$ & 243.50 & $1,680.5$ & 189.89 & 78.0 \\
\hline & Kawasima & 292.0 & $1980-2013$ & $2,043.7$ & 596.75 & $1,538.8$ & 449.34 & 75.3 \\
\hline & Kanrokuvasi & 366.0 & 1980-2013 & $1,877.4$ & 687.13 & $1,337.0$ & 489.35 & 71.2 \\
\hline & Hinodevasi & 695.0 & $1980-2013$ & $1,936.8$ & $1,346.05$ & $1,407.3$ & 978.06 & 72.7 \\
\hline & Miyatavasi & 123.0 & $1981-2013$ & $1,613.9$ & 198.51 & $1,045.8$ & 128.63 & 64.8 \\
\hline & Karakuma & 887.0 & 1980-2013 & $1,890.6$ & $1,676.96$ & $1,350.9$ & $1,198.26$ & 71.5 \\
\hline & Nakama & 925.0 & 1980-2013 & $1,890.6$ & $1,748.80$ & $1,350.9$ & $1,249.59$ & 71.5 \\
\hline
\end{tabular}


flow amount due to expression of unit area, $\mathrm{km}^{2}$. Using unit of $\mathrm{mm}$, streamflows were compared in a more relatively method.

Table 3 shows Korean results, and Table 4 shows Japanese results. The flow durations with 10 year frequency were compared, in which the $1^{\text {st }}$ flows were $18.77 \mathrm{~mm}$ in Korea and $88.27 \mathrm{~mm}$ in Japan, the $95^{\text {th }}$ flows

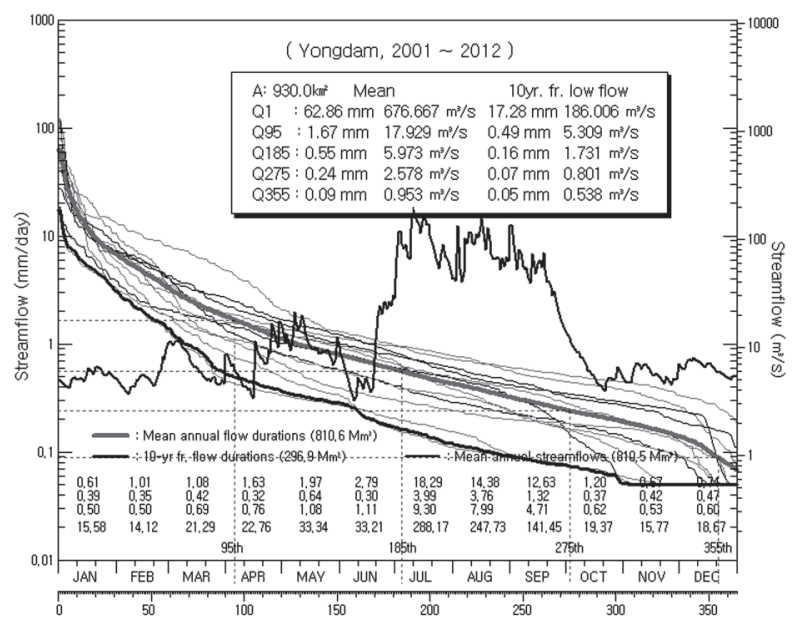

Fig. 16. An example of flow duration curve derived in Yongdam dam, Korea.

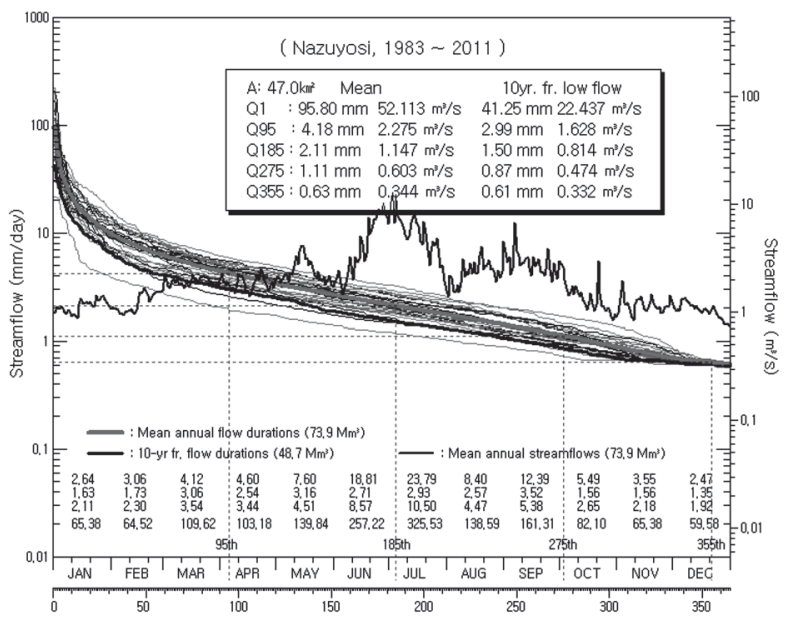

Fig. 17. An example of flow duration curve derived in Nazuyosi station, Japan. of 0.43 and 3.97 , the $185^{\text {th }}$ of 0.13 and 1.92 , the $275^{\text {th }}$ of 0.06 and 0.93 , and the $355^{\text {th }}$ of 0.05 and 0.30 , respectively. Japanese flows were more 4 to 15 times than Korean. On the other hand, mean flow durations showed the $1^{\text {st }}$ flows of $67.11 \mathrm{~mm}$ and 88.27 , the $95^{\text {th }}$ of 1.58 and 3.97 , the $185^{\text {th }}$ of 0.51 and 1.92 , the $275^{\text {th }}$ of 0.21 and 0.93 , and the $355^{\text {th }}$ of 0.08 and 0.30 , respectively. Japanese flows also showed more 1.3 to 4.4 times than Korean.

\section{Comparison of streamflows in Korean and Japanese river}

Daily streamflow data were compared to find maximum, minimum, mean values during all years each month in Korean and Japanese watersheds. Korean showed higher than Japanese only in August and September as shown in Table 5.

Annual mean daily streamflows were superposed by station, and its values were averaged among Korean and Japanese data. Resulted mean data were compared, in which Japanese data showed higher than Korean without mid July to mid September as shown in Fig. 18. Mean annual streamflow data also showed that the Japanese were higher than the Korean as shown in Fig. 19.

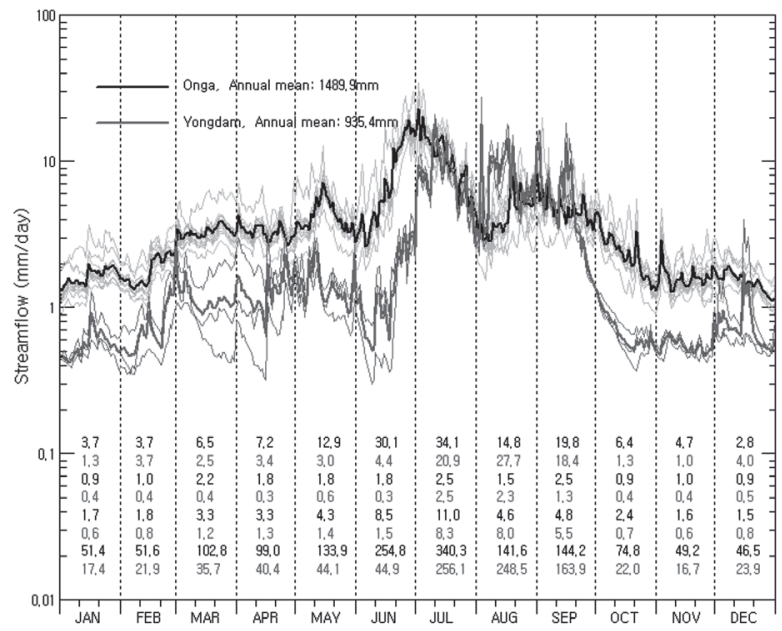

Fig. 18. Comparison of daily streamflow on maximum, minimum, mean, and sum between Korean Yongdam and Japanese Onga river basin.

Table 3. Result of flow duration analysis on Korean watersheds

\begin{tabular}{|c|c|c|c|c|c|c|c|c|c|c|c|}
\hline Watershed & Divide & \multicolumn{2}{|c|}{$1^{\text {st }}$ flow } & \multicolumn{2}{|c|}{$95^{\text {th }}$ flow } & \multicolumn{2}{|c|}{$185^{\text {th }}$ flow } & \multicolumn{2}{|c|}{$275^{\text {th }}$ flow } & \multicolumn{2}{|c|}{$355^{\text {th }}$ flow } \\
\hline \multirow{2}{*}{ Cheoncheon } & Mean & 69.43 & 233.76 & 1.64 & 5.53 & 0.54 & 1.83 & 0.21 & 0.72 & 0.09 & 0.30 \\
\hline & $10 \mathrm{yr}$ & 20.83 & 70.13 & 0.45 & 1.53 & 0.12 & 0.40 & 0.05 & 0.17 & 0.05 & 0.17 \\
\hline Donghang & Mean & 69.03 & 131.35 & 1.44 & 2.73 & 0.43 & 0.81 & 0.18 & 0.33 & 0.07 & 0.13 \\
\hline \multirow{2}{*}{ Yongdam } & Mean & 62.86 & 676.67 & 1.67 & 17.93 & 0.55 & 5.97 & 0.24 & 2.58 & 0.09 & 0.95 \\
\hline & $10 y r$ & 17.28 & 186.01 & 0.49 & 5.31 & 0.16 & 1.73 & 0.07 & 0.80 & 0.05 & 0.54 \\
\hline
\end{tabular}


Table 4. Result of flow duration analysis on Japanese watersheds

\begin{tabular}{|c|c|c|c|c|c|c|c|c|c|c|c|}
\hline \multirow{2}{*}{ Watershed } & \multirow{2}{*}{ Divide } & \multicolumn{2}{|c|}{$1^{\text {st }}$ flow } & \multicolumn{2}{|c|}{$95^{\text {th }}$ flow } & \multicolumn{2}{|c|}{$185^{\text {th }}$ flow } & \multicolumn{2}{|c|}{$275^{\text {th }}$ flow } & \multicolumn{2}{|c|}{$355^{\text {th }}$ flow } \\
\hline & & $\mathrm{mm}$ & $\mathrm{m}^{3} / \mathrm{s}$ & $\mathrm{mm}$ & $\mathrm{m}^{3} / \mathrm{s}$ & $\mathrm{mm}$ & $\mathrm{m}^{3} / \mathrm{s}$ & $\mathrm{mm}$ & $\mathrm{m}^{3} / \mathrm{s}$ & $\mathrm{mm}$ & $\mathrm{m}^{3} / \mathrm{s}$ \\
\hline \multirow{2}{*}{ Soeda } & Mean & 112.39 & 98.86 & 5.70 & 5.01 & 2.73 & 2.40 & 1.35 & 1.18 & 0.48 & 0.42 \\
\hline & $10 \mathrm{yr}$ & 59.98 & 52.76 & 4.05 & 3.56 & 1.93 & 1.69 & 0.93 & 0.82 & 0.38 & 0.34 \\
\hline \multirow{2}{*}{ Ida } & Mean & 87.79 & 129.05 & 4.36 & 6.40 & 2.16 & 3.17 & 1.07 & 1.58 & 0.35 & 0.51 \\
\hline & $10 \mathrm{yr}$ & 32.48 & 47.74 & 2.75 & 4.04 & 1.44 & 2.12 & 0.64 & 0.94 & 0.15 & 0.22 \\
\hline \multirow{2}{*}{ Nazuyosi } & Mean & 95.80 & 52.11 & 4.18 & 2.27 & 2.11 & 1.15 & 1.11 & 0.60 & 0.63 & 0.34 \\
\hline & $10 \mathrm{yr}$ & 41.25 & 22.44 & 2.99 & 1.63 & 1.50 & 0.81 & 0.87 & 0.47 & 0.61 & 0.33 \\
\hline \multirow{2}{*}{ Kasgavasi } & Mean & 80.67 & 67.22 & 3.42 & 2.85 & 1.67 & 1.39 & 0.75 & 0.63 & 0.22 & 0.19 \\
\hline & $10 \mathrm{yr}$ & 25.59 & 21.32 & 1.97 & 1.64 & 0.88 & 0.73 & 0.39 & 0.32 & 0.05 & 0.04 \\
\hline \multirow{2}{*}{ Akaike } & Mean & 82.97 & 296.72 & 4.09 & 14.61 & 2.05 & 7.34 & 1.02 & 3.63 & 0.32 & 1.13 \\
\hline & $10 \mathrm{yr}$ & 33.17 & 118.61 & 2.62 & 9.38 & 1.37 & 4.91 & 0.63 & 2.26 & 0.14 & 0.48 \\
\hline \multirow{2}{*}{ Nakasima } & Mean & 81.34 & 306.90 & 3.91 & 14.74 & 1.96 & 7.41 & 0.97 & 3.67 & 0.31 & 1.17 \\
\hline & $10 \mathrm{yr}$ & 30.58 & 115.38 & 2.33 & 8.79 & 1.28 & 4.82 & 0.59 & 2.22 & 0.11 & 0.43 \\
\hline \multirow{2}{*}{ Ookuma } & Mean & 100.10 & 48.66 & 4.26 & 2.07 & 1.97 & 0.96 & 0.94 & 0.46 & 0.28 & 0.14 \\
\hline & $10 \mathrm{yr}$ & 38.95 & 18.93 & 2.55 & 1.24 & 1.18 & 0.57 & 0.56 & 0.27 & 0.15 & 0.07 \\
\hline \multirow{2}{*}{ Akimazuvasi } & Mean & 110.68 & 144.76 & 4.27 & 5.58 & 2.04 & 2.66 & 0.99 & 1.30 & 0.30 & 0.39 \\
\hline & $10 \mathrm{yr}$ & 49.06 & 64.16 & 2.65 & 3.46 & 1.40 & 1.84 & 0.62 & 0.81 & 0.17 & 0.22 \\
\hline \multirow{2}{*}{ Kawasima } & Mean & 95.39 & 322.40 & 4.02 & 13.59 & 1.88 & 6.35 & 0.91 & 3.08 & 0.27 & 0.92 \\
\hline & $10 \mathrm{yr}$ & 39.79 & 134.49 & 2.25 & 7.60 & 1.21 & 4.08 & 0.52 & 1.74 & 0.11 & 0.37 \\
\hline \multirow{2}{*}{ Kanrokuvasi } & Mean & 82.78 & 350.65 & 3.53 & 14.93 & 1.64 & 6.96 & 0.78 & 3.31 & 0.22 & 0.95 \\
\hline & $10 \mathrm{yr}$ & 39.18 & 165.96 & 1.92 & 8.12 & 0.96 & 4.08 & 0.41 & 1.75 & 0.07 & 0.29 \\
\hline \multirow{2}{*}{ Hinodevasi } & Mean & 82.39 & 662.72 & 3.78 & 30.42 & 1.80 & 14.50 & 0.85 & 6.87 & 0.25 & 2.00 \\
\hline & $10 \mathrm{yr}$ & 34.53 & 277.76 & 2.16 & 17.37 & 1.17 & 9.38 & 0.52 & 4.22 & 0.10 & 0.77 \\
\hline \multirow{2}{*}{ Miyatavasi } & Mean & 64.38 & 91.66 & 2.85 & 4.06 & 1.39 & 1.98 & 0.64 & 0.91 & 0.15 & 0.21 \\
\hline & $10 \mathrm{yr}$ & 24.34 & 34.66 & 1.64 & 2.34 & 0.77 & 1.09 & 0.34 & 0.48 & 0.05 & 0.07 \\
\hline \multirow{2}{*}{ Karakuma } & Mean & 79.57 & 816.91 & 3.63 & 37.24 & 1.73 & 17.81 & 0.82 & 8.45 & 0.23 & 2.39 \\
\hline & $10 \mathrm{yr}$ & 34.41 & 353.29 & 2.07 & 21.26 & 1.12 & 11.51 & 0.48 & 4.93 & 0.08 & 0.86 \\
\hline \multirow{2}{*}{ Nakama } & Mean & 79.57 & 851.91 & 3.63 & 38.83 & 1.73 & 18.57 & 0.82 & 8.81 & 0.23 & 2.49 \\
\hline & $10 \mathrm{yr}$ & 34.41 & 368.43 & 2.07 & 22.17 & 1.12 & 12.00 & 0.48 & 5.14 & 0.08 & 0.90 \\
\hline
\end{tabular}

Table 5. Comparison of daily maximum, minimum, mean values, and monthly sum in each month between Korean Yongdam dam and Japanese Onga river basins

\begin{tabular}{|c|c|c|c|c|c|c|c|c|c|c|c|c|c|}
\hline River & Month & 1 & 2 & 3 & 4 & 5 & 6 & 7 & 8 & 9 & 10 & 11 & 12 \\
\hline \multirow{4}{*}{$\begin{array}{l}\text { Yongdam } \\
\text { dam }\end{array}$} & $\operatorname{Max} .(\mathrm{mm} / \mathrm{d})$ & 1.3 & 3.7 & 2.5 & 3.4 & 3.0 & 4.4 & 20.9 & 27.7 & 18.4 & 1.3 & 1.0 & 4.0 \\
\hline & Min. (mm/d) & 0.4 & 0.4 & 0.4 & 0.3 & 0.6 & 0.3 & 2.5 & 2.3 & 1.3 & 0.4 & 0.4 & 0.5 \\
\hline & Mean $(\mathrm{mm} / \mathrm{d})$ & 0.6 & 0.8 & 1.2 & 1.3 & 1.4 & 1.5 & 8.3 & 8.0 & 5.5 & 0.7 & 0.6 & 0.8 \\
\hline & Sum (mm) & 17.4 & 21.9 & 35.7 & 40.3 & 44.1 & 44.9 & 256.1 & 248.5 & 163.9 & 22.0 & 16.7 & 23.9 \\
\hline \multirow{4}{*}{ Onga } & $\operatorname{Max} .(\mathrm{mm} / \mathrm{d})$ & 3.7 & 3.7 & 6.5 & 7.2 & 12.9 & 30.1 & 34.1 & 14.8 & 19.8 & 6.4 & 4.7 & 2.8 \\
\hline & Min. $(\mathrm{mm} / \mathrm{d})$ & 0.9 & 1.0 & 2.2 & 1.8 & 1.8 & 1.8 & 2.5 & 1.5 & 2.5 & 0.9 & 1.0 & 0.9 \\
\hline & Mean $(\mathrm{mm} / \mathrm{d})$ & 1.7 & 1.8 & 3.3 & 3.3 & 4.3 & 8.5 & 11.0 & 4.6 & 4.8 & 2.4 & 1.6 & 1.5 \\
\hline & Sum (mm) & 51.4 & 51.6 & 102.8 & 99.0 & 133.9 & 254.8 & 340.3 & 141.6 & 144.2 & 74.8 & 49.2 & 46.5 \\
\hline
\end{tabular}

Distributions of annual rainfall and streamflow on Yongdam dam and Onga river basin were expressed and compared as shown in Fig. 20 and Fig. 21, respectively. Numbers of station-year were 38 on Korea and 436 on Japan. Annual rainfalls were averaged to $1418.1 \mathrm{~mm}$ ranged from $778.2 \mathrm{~mm}$ to $2061.9 \mathrm{~mm}$ on Korea and were averaged to $1972.5 \mathrm{~mm}$ ranged from $845.0 \mathrm{~mm}$ to $3623.0 \mathrm{~mm}$ on Japan, from which Japanese showed 1.39 times more than Korean. Simulated annual stream- flows were averaged to $854.2 \mathrm{~mm}$ ranged from $273.6 \mathrm{~mm}$ to $1571.4 \mathrm{~mm}$ on Korea and were averaged to $1481.6 \mathrm{~mm}$ ranged from $360.6 \mathrm{~mm}$ to $3177.4 \mathrm{~mm}$ on Japan, from which Japanese showed 1.73 times more than Korean. Mean annual runoff ratios were 58.2\% ranged from $35.2 \%$ to $76.2 \%$ on Korean river, and were $73.7 \%$ from $42.6 \%$ to $90.0 \%$ on Japanese river. Japanese runoff ratio also showed 1.27 times more than Korean. 


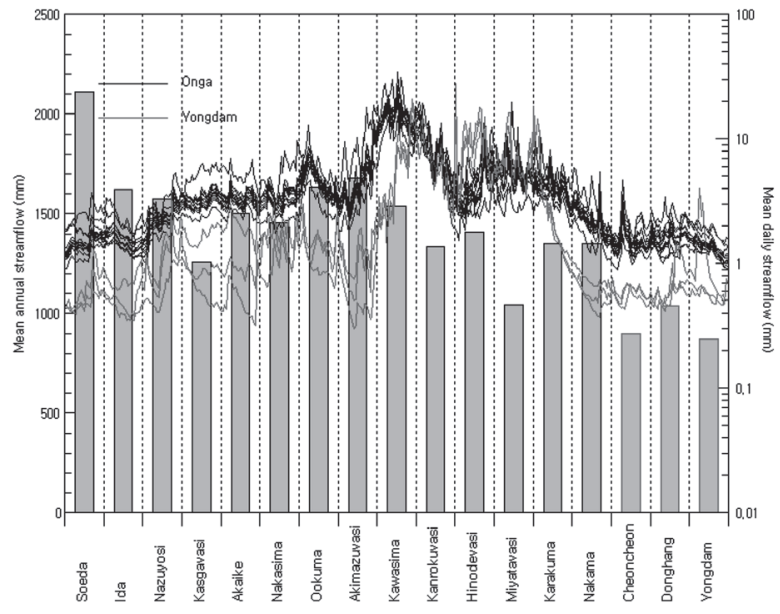

Fig. 19. Comparison of annual streamflow on maximum, minimum, mean, and sum between Korean Yongdam and Japanese Onga river basin.

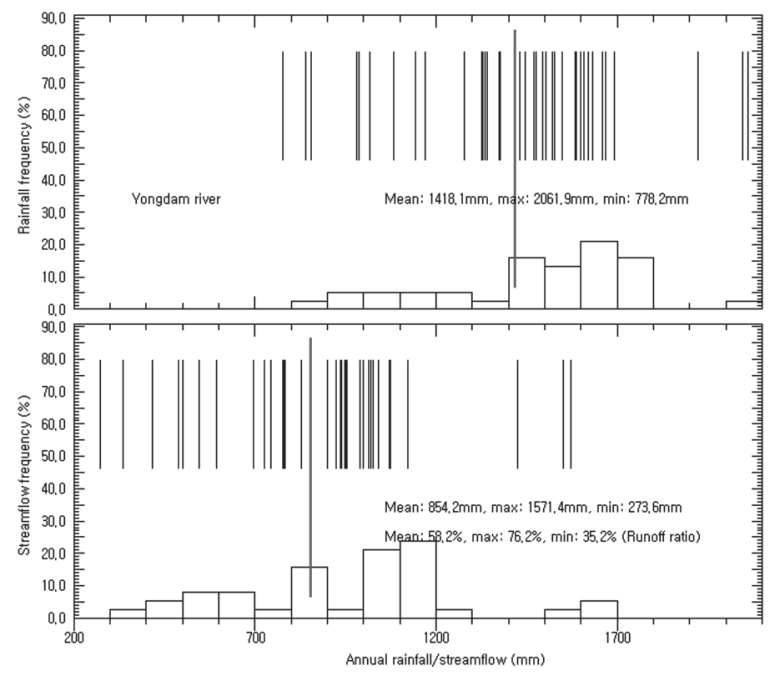

Fig. 20. Distributions of annual rainfall and streamflow on Yongdam dam watershed.

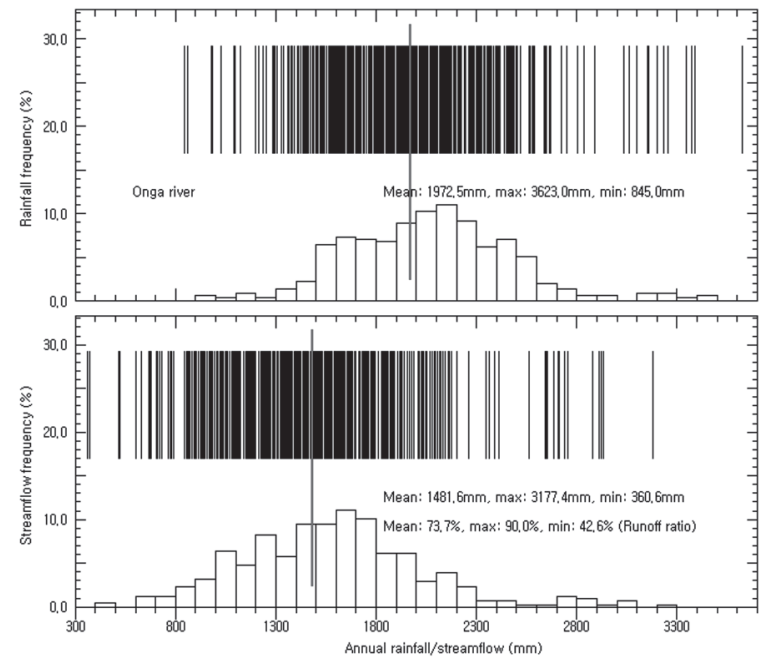

Fig. 21. Distributions of annual rainfall and streamflow on Onga river basin.

\section{DISCUSSION}

To compare water quantity on Korean and Japanese rivers, watersheds with similar area were selected. The one from Korea is called the Yongdam dam watershed in the Geum river basin with watershed area of $930 \mathrm{~km}^{2}$, the other from Japan is called the Nakama watershed in the Onga river basin with watershed area of $925 \mathrm{~km}^{2}$. The 3 discharge stations from Korea and 14 discharge stations from Japan were selected and analyzed to determine flow duration.

Daily evaporation data in Japan were generated with function of temperature, rainfall, wind speed, humidity, and sunshine hour using meteorological data at the Izuka and Soeda stations, which was verified from evaporation data of Daejeon meteorological station with the observed data in Korea. Korean data were collected during 2000 to 2014 from water management information system. Japanese rainfall and discharge data were collected during 1980 to 2013 from water information system. Numbers of station-year were 38 on Korea and 436 on Japan.

Annual rainfalls were averaged to $1418.1 \mathrm{~mm}$ ranged from $778.2 \mathrm{~mm}$ to $2061.9 \mathrm{~mm}$ on Korea and $1972.5 \mathrm{~mm}$ ranged from $845.0 \mathrm{~mm}$ to $3623.0 \mathrm{~mm}$ on Japan, from which the Japanese showed 1.39 times more than the Korean.

Simulated annual streamflows were averaged to $854.2 \mathrm{~mm}$ ranged from $273.6 \mathrm{~mm}$ to $1571.4 \mathrm{~mm}$ on Korea and $1481.6 \mathrm{~mm}$ ranged from $360.6 \mathrm{~mm}$ to $3177.4 \mathrm{~mm}$ on Japan, from which Japanese showed 1.73 times more than Korean.

The flow durations with 10 year frequency were compared, in which the 1st flows were $18.77 \mathrm{~mm}$ in Korea and $88.27 \mathrm{~mm}$ in Japan, the $95^{\text {th }}$ flows of 0.43 and 3.97 , the $185^{\text {th }}$ of 0.13 and 1.92 , the $275^{\text {th }}$ of 0.06 and 0.93 , and the $355^{\text {th }}$ of 0.05 and 0.30 , respectively. The Japanese flows were more 4 to 15 times than the Korean.

Mean flow durations showed the $1^{\text {st }}$ flows of 67.11 $\mathrm{mm}$ and 88.27 , the $95^{\text {th }}$ of 1.58 and 3.97 , the $185^{\text {th }}$ of 0.51 and 1.92 , the $275^{\text {th }}$ of 0.21 and 0.93 , and the $355^{\text {th }}$ of 0.08 and 0.30 , respectively. The Japanese flows also showed 1.3 to 4.4 times more than those in the Korean.

Mean annual runoff ratios were $58.2 \%$ ranged from $35.2 \%$ to $76.2 \%$ on Korean river, and were $73.7 \%$ from $42.6 \%$ to $90.0 \%$ on Japanese river. The Japanese runoff ratio also showed 1.27 times more than those in the Korean.

This result shows some more necessities and difficulties on low flow management in Korean river than in Japanese river.

\section{AUTHOR CONTRIBUTIONS}

Jaekyoung NOH carried out substantial contribution to the concept and design on this paper. Hyunuk AN and Taek-Keun $\mathrm{OH}$ carried out analysis and interpretation of data. Yoshiyuki SHINOGI verified the Japan's data. Jaenam LEE supervised the project, analyzed the 
data and wrote the paper. All authors commented on the manuscript.

\section{ACKNOWLEDGMENT}

This work was supported by research fund of Chungnam National University, Republic of Korea.

\section{REFERENCES}

Alcázar, J. and A. Palau 2010 Establishing environmental flow regimes in a Mediterranean watershed based on a regional classification. J. Hydrology, 388: 41-51

Chang, F. J., M. J. Tsai, W. P. Tsai and E. E. Herricks 2008 Assessing the ecological hydrology of natural flow conditions in Taiwan. J. Hydrology, 354: 75-89

Chang, F. J., W. P. Tsai, T. C. Wu, H. K. Chen and E. E. Herricks 2011 Identifying natural flow regimes using fish communities. J. Hydrology, 409: 328-336

Jee, Y. K., M. S. Lee, J. H. Lee and J. H. Jang 2012 Analysis of water quality improvement in downstream river of heightening irrigation dam through the reservoir operation. J. Korea Water Resources Association, 45(9): 929-941 [in Korean]

Kang, S., C. Yoo, D. Lee and S. Choi 2016 Improvement of instream flow evaluation methodology and application, $J$. Korean Society of Hazard Mitigation, 16(1): 295-304 [in Korean]

Kim, H. J. 2001 Development of Two-parametric Hyperbolic Model for Daily Streamflow Simulation. Ph. D. Dissertation, Seoul National University, Seoul, Korea, 158 pp. [in Korean]

King, J. and D. Louwb 1998 Instream flow assessments for regulated rivers in South Africa using the building block methodology. Aquatic Ecosystem Health and Management, 1: 109124

Li, F., Q. Cai, X. Fu and J. Liu 2009 Construction of habitat suitability models (HSMs) for benthic macroinvertebrate and their applications to instream environmental flows: A case study in Xiangxi river of Three Gorges Reservior region, China. Progress in Natural Science, 19: 359-367

MOE (Ministry of Environmnet) 2015 Management System on
Water Quality Total Load, 48p. available online at http:// tmdlms.nier.go.kr/ [in Korean]

NIER (National Institute of Environmental Research) 2014 Technical Guidelines for Water Pollution Total Load Management. NIER, Incheon, Korea [in Korean]

Noh, J. and J. Lee 2012 Assessing reservoir site and size for irrigation to upland area in Dodota, Ethiopia. KCID J., $\mathbf{1 9}(2)$ 89-97 [in Korean]

Noh, J. and J. Lee 2011 Comparison of streamflow runoff model in Korea for applying to reservoir operation. CNU Journal of Agricultural Science, 38(3): 513-514[in Korean]

Noh, J. 1991 A Conceptual Watershed Model for Daily Streamflow Based on Soil Water Storage. Ph. D. Dissertation, Seoul National University, Seoul, Korea, 183 pp.[in Korean]

Noh, J. and J. Lee. 2012. Affecting Reservoir Inflow by Applying Estimated Evaporation. Abstracts of The 2012 KSAE Annual Conference, 18-19 September 2012 [in Korean]

Petts, G. E. 2009 Instream flow science for sustainable river management. J. American Water Resources Association, 45: $1071-1086$

Poff, N. L., J. D. Allan, M. B. Bain, J. R. Karr, K. L. Prestegaard, B. D. Richter, R. E. Sparks and J. C. Stromberg 1997 The natural flow regime. Bioscience, 47: 769-784

Richter, B., J. Baumgartner, R. Wigington and D. Braun 1997 How much water does a river need? Freshwater Biology, $\mathbf{3 7}$ 231-249

Smakhtin,V. U. 2001 Low flow hydrology: A review. J. Hydrology, 240: $147-186$

Snelder, T. H., N. Lamouroux, J. R. Leathwick, H. Pella, E. Sauquet and U. Shankar 2009 Predictive mapping of the natural flow regimes of France. J. Hydrology, 373: 57-67

Tharme, R. E. 2003 A global perspective on environmental flow assessment: Emerging trend in the development and application of environmental flow methodologies for rivers. River Research and Applications, 19: 397-442

Tran, T. A., Y. Mitani, H. Ikemi and H. Matsuki 2011 Human impacts on erosion and deposition in Onga river basin Kyushu, Japan. Memoirs of the Faculty of Engineering, Kyushu University, 71(2): 47-65

Wen, L. 2009 Reconstruction natural flow in a regulated system, the Murrumbidgee river, Australia, using time series analysis. J. Hydrology, 364: 216-226 